\title{
Health Risks to Computer Workers in Various Indoor Facilities
}

\author{
Piia Tint ${ }^{1}$, Viiu Tuulik ${ }^{2}$, Deniss Karai ${ }^{3}$, Kalju Meigas ${ }^{4},{ }^{1-4}$ Tallinn University of Technology
}

\begin{abstract}
Musculoskeletal disorders (MSDs) are the main cause of occupational diseases in Estonia and Europe. The number of MSDs has increased with the increasing number of computer workers and the increasing workload overall. In the current paper, the survey of 295 workers in Estonian enterprises is carried out to clarify the reasons of occupational stress. The causes of occupational stress are non-ergonomically designed workplace, social and human factors. The main questionnaires used were KIVA and GPSnordic. The conclusion is that KIVA questionnaire alone is too mild to point out the risk factors. The comparison with other questionnaires has to be carried out.
\end{abstract}

Keywords: computer workers, GPSnordic questionnaire, KIVA questionnaire, occupational diseases.

\section{INTRODUCTION}

The human body responds to stress factors through four systems - central nervous, automatic nervous, endocrine and immune - which are constantly interacting as a complex network [1]. The psychological, physiological and social factors affect office workers daily. The supplementary hazardous factors in the work environment might be draught, bad lighting or bad smells causing sick building syndrome [2]. The main physiological stress factor at workplace is badly designed workplace [3]. The number of occupational diseases is the specific indicator of influence of existing hazards and risk factors on the worker in the work environment [4]. The occupational diseases in Estonia are usually diagnosed in the late stage when the worker is already disabled. The main part of occupational diseases nowadays is connected with the musculoskeletal disorders (MSDs) [5], [6] in Estonia, Latvia and all over the European Union. The increasing amount of computer work and workers in the society is a supplementary source for developing the MSDs. In the current paper, the physiological and psychological stress connected with the social factors at work and outside the work is investigated. The workload is increasing, but the working conditions are not developing so fast. The preventive measures in occupational safety and health are often not used as these measures cause the supplementary costs for the employers [7].

Social relationships are important for the physical health of the workers [8]. The socially connected people live longer than socially isolated people [9] and the first have increased resistance to a variety of somatic diseases ranging from heart disease to cancer [10]. There is an increasing flexibility related to how work can be done today. Work is not bound by time and place anymore due to information technologies. The risk is that the employee well-being will decrease as the amount of work to be done increases. The pressure to perform better and more at work has also increased. This may lead to a higher level of stress and burnouts. The work is not bound to a specific time and room, so that the line between personal and work life may be increasingly blurred (Fig. 1). The impact of psychosocial risk factors on the well-being at work has been investigated and analyzed by J. Seppo [11]. The Estonian workers have enough time to finish their work; $86.5 \%$ of them have a feeling that the work has been done well; $77 \%$ get the support from the co-workers; $51.5 \%$ get the support and help from the leaders; $40.6 \%$ have a possibility to influence the important work related decisions; $5.6 \%$ of the workers have to comply with the duties that are not acceptable by their own values.

The holistic image of work ability [12] consists of both the resources of the individual and factors related to work and the environment outside the work. The dimensions of work ability can be depicted in the form of a work ability house (Fig. 1), its floors, and the surrounding environment.

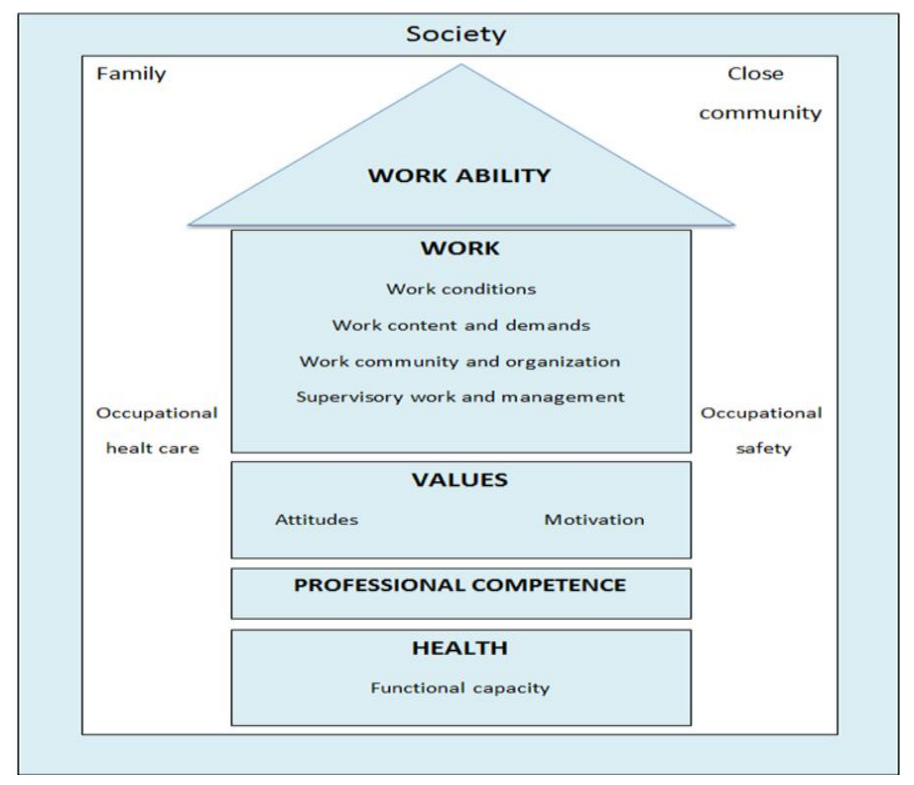

Fig. 1. Work ability house.

\section{MATERIALS AND METHODS}

The investigation has been carried out within the framework of WASI (Work Ability and Social Inclusion) project. The purpose of the project was to increase the work ability, stress management, good leadership behavior and thereby social inclusion of the work force. The aim of the study was to improve the leadership stress management and the communication within the organizations. 295 workers 
from different enterprises (energy, services) and a high school as a control group were questioned about health risks in the work environment and health disturbances connected with their work.

The QPSnordic [13] and KIVA [14] questionnaires were used for investigating the stress factors arising from the relationship between the employers and employees at the workplace.

Part of the QPSnordic consists of the following questions:

1. Does your immediate superior encourage you to speak up, when you have different opinions?

2 . Does the immediate superior encourage you to participate in important decisions?

3. Does your immediate superior help you develop your skills?

4. Does your immediate superior tackle problems as soon as they arise?

5. Do you trust the ability of the management to look after the future of the company/organization?

6. Does your immediate superior distribute the work fairly and impartially?

7. Does your immediate superior treat workers fairly and equally?

8. Is the relationship between you and your immediate superior a source of stress to you?

The marks were given as follows: 1) very little or not at all; 2) rather little; 3) somewhat; 4) rather much; 5) very much.

These questions were chosen as they are more close to KIVA questionnaire.

The KIVA questionnaire consists of the following questions:

1. Have you enjoyed coming to work in the last weeks?

2. I regard my job meaningful;

3. I feel in control of my work;

4. I get on with my fellow workers;

5. My immediate superior performs as a superior;

6. How certain are you that you will keep the job with this employer?

7. How much can you influence factors concerning your job?

The marks were given from 1 (not at all) to 8 (very much so, certain or well).

The firms and enterprises (7) were chosen from service, energy and higher education area. The office rooms of the investigated firms were different (Fig. 2-7). The service enterprise office room (computer center) was built in 1986. It has overgone some repairs (Fig. 2). The office room of the energy enterprise is 10 years old and opened type (Fig. 3). The high-school building is atrium-type (Fig.4) and there are different problems in the workrooms close to the atrium (Fig.4) in autumn and winter season (for example the lack of natural lighting). In spring and summer there are problems with very hot indoor air (over 30 degrees) in the rooms outside the atrium (Fig. 6). The design of the office workrooms is not the appropriate every time. The rule is that ergonomics has to be taken into account already during the design of the building; afterwards it is very difficult to improve something. In the new buildings usually also the furniture is bought for the entire house, so that the workers seldom can influence the choice of their chair or table. The ergonomic furniture has to be bought considering the anthropologic measures of the worker. Therefore, the indoor environment hazards might be also the sources of stress on the individual and team level for office workers. The greatest problems with the work environment are before the repairs and after the repairs during a half of the year. After that the workers get acquainted with the new conditions and do not complain anymore so often as in the beginning. The problems are related with ventilation, shortage of natural lighting or too strong luminescence lamps in the room. The glare from the screen is also a factor that burdens workers.

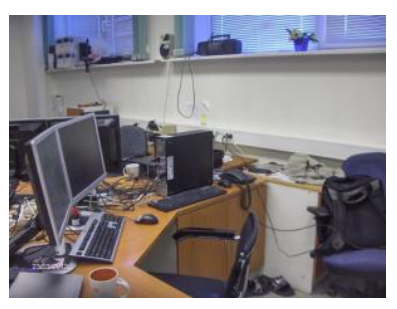

Fig. 2. The office room of the service enterprise (computer centre)

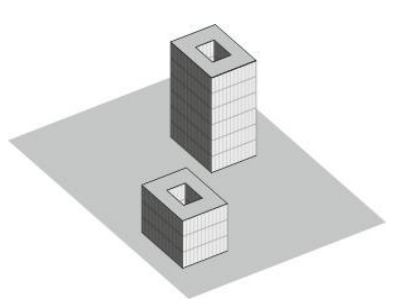

Fig. 4. Atrium-type buildings of university.

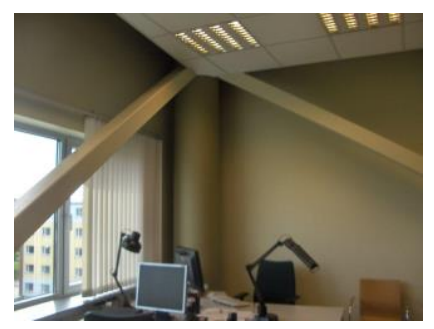

Fig. 6. Workroom outside the (badly designed) workplaces.

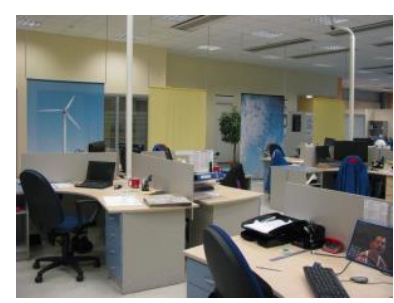

Fig. 3. The opened office of a big and successful energy enterprise.

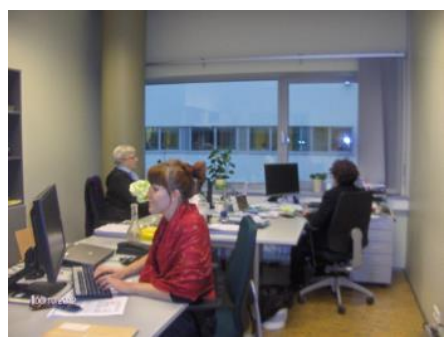

Fig.5. The work room close to the inside atrium.

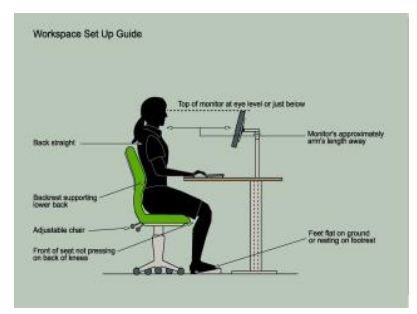

Fig .7. Ergonomic design of the atrium.

\section{THE RESULTS}

The results of the questionnaire are presented in Table 1 and Table 2. The workers of the three investigated firms were divided into two groups: at the age of less than 40 years and over 40 years (included). The questionnaire consisted of 67 questions. In the tables there is given only part of QPSnordic questionnaire to clarify the relations between the employer and employee. The other questions concerned the medical history of the persons. The permission to carry out that questionnaire was received from the Ethic Committee of Estonia. The workers were very interested in the survey and they were given the feedback. 
TABLE I

THE FEELING OF STRESS BY THE WORKERS (GPSNORDIC QUESTIONNAIRE)

\begin{tabular}{|c|c|c|c|c|c|c|}
\hline QUESTION & $\begin{array}{c}\text { Energy } \\
\text { enterprise } \\
\text { A }\end{array}$ & $\begin{array}{c}\text { Service } \\
\text { enterprise } \\
\text { B }\end{array}$ & $\begin{array}{c}\text { The high } \\
\text { school, } \\
\text { workers' } \\
\text { age }<40 \\
\text { years }\end{array}$ & $\begin{array}{c}\text { The high } \\
\text { school, } \\
\text { workers' age } \\
>40 \text { years } \\
\text { C } \\
\end{array}$ & $\begin{array}{c}\text { The total } \\
\text { sample, } \\
<40 \text { years, } \\
137 \\
\text { workers }\end{array}$ & $\begin{array}{c}\text { The total } \\
\text { sample, } \\
>40 \text { years, } \\
154 \\
\text { workers } \\
\end{array}$ \\
\hline $\begin{array}{l}\text { 1. Does your immediate superior encourage you to speak } \\
\text { up, when you have different opinions? }\end{array}$ & 3.33 & 3.55 & 3.37 & 3.07 & 3.38 & 3.07 \\
\hline $\begin{array}{l}\text { 2. Does the immediate superior encourage you to } \\
\text { participate in important decisions? }\end{array}$ & 3.42 & 3.59 & 3.58 & 3.23 & 3.55 & 3.11 \\
\hline $\begin{array}{l}\text { 3. Does your immediate superior help you develop your } \\
\text { skills? }\end{array}$ & 3.70 & 3.64 & 4.05 & 3.52 & 3.9 & 3.47 \\
\hline $\begin{array}{l}\text { 4. Does your immediate superior tackle problems as soon as } \\
\text { they arise? }\end{array}$ & 3.66 & 4.00 & 3.85 & 3.66 & 3.77 & 3.65 \\
\hline $\begin{array}{l}\text { 5. Do you trust the ability of the management to look after } \\
\text { the future of the company/organization? }\end{array}$ & 4.33 & 3.86 & 3.77 & 3.67 & 3.82 & 3.66 \\
\hline $\begin{array}{l}\text { 6. Does your immediate superior distribute the work fairly } \\
\text { and impartially? }\end{array}$ & 3.97 & 4.09 & 3.89 & 3.78 & 3.93 & 3.70 \\
\hline $\begin{array}{l}\text { 7. Does your immediate superior treat workers fairly and } \\
\text { equally? }\end{array}$ & 4.06 & 4.09 & 3.95 & 3.89 & 3.97 & 3.82 \\
\hline $\begin{array}{l}\text { 8. Is the relationship between you and your immediate } \\
\text { superior a source of stress to you? }\end{array}$ & 1.88 & 1.77 & 1.80 & 1.83 & 1.83 & 1.89 \\
\hline
\end{tabular}

TABLE 2

THE FEELING OF STRESS BY THE WORKERS (KIVA QUESTIONNAIRE)

\begin{tabular}{|c|c|c|c|c|c|c|c|c|c|c|c|}
\hline QUESTION & $\begin{array}{l}\text { Energy } \\
\text { enterprise } \\
\text { total } \\
\quad \text { A }\end{array}$ & $\begin{array}{l}\begin{array}{l}\text { Energy } \\
\text { enterprise }\end{array} \\
\text { workers' } \\
\text { age }<40 \\
\text { years }\end{array}$ & $\begin{array}{l}\text { Energy } \\
\text { enterprise } \\
, \\
\text { workers' } \\
\text { age }>40 \\
\text { years }\end{array}$ & $\begin{array}{l}\text { Service } \\
\text { enter- } \\
\text { prise, } \\
\text { total } \\
\text { B }\end{array}$ & $\begin{array}{l}\text { Service } \\
\text { enter- } \\
\text { prise, } \\
\text { worker } \\
\text { s' age } \\
<40 \\
\text { years }\end{array}$ & $\begin{array}{l}\text { Service } \\
\text { enter- } \\
\text { prise, } \\
\text { worker } \\
\text { s'age } \\
>40 \\
\text { years }\end{array}$ & $\begin{array}{l}\text { The high } \\
\text { school, } \\
\text { workers' } \\
\text { age <40 } \\
\text { years } \\
\text { C }\end{array}$ & $\begin{array}{l}\text { The high } \\
\text { school, } \\
\text { workers' } \\
\text { age }>40 \\
\text { years }\end{array}$ & $\begin{array}{l}\text { Total } \\
\text { sample } \\
\text {, } \\
\text { worker } \\
\text { s' } \\
\text { years } \\
<40\end{array}$ & $\begin{array}{l}\text { Total } \\
\text { sample } \\
\text {, } \\
\text { worker } \\
\text { s'age } \\
>40\end{array}$ & $\begin{array}{l}\text { Total } \\
\text { sample }\end{array}$ \\
\hline $\begin{array}{l}\text { 1. Have you enjoyed coming } \\
\text { to work in the last weeks? }\end{array}$ & 6.2 & 6.2 & 6.3 & 6.8 & 5.7 & 7.6 & 7.3 & 7.2 & 6.7 & 7.1 & 6.9 \\
\hline $\begin{array}{l}\text { 2. I regard my job } \\
\text { meaningful }\end{array}$ & 8.3 & 8.0 & 9.1 & 8.4 & 7.9 & 8.9 & 7.0 & 8.4 & 8.2 & 8.4 & 8.3 \\
\hline $\begin{array}{l}\text { 3. I feel in control of my } \\
\text { work }\end{array}$ & 7.5 & 7.0 & 8.7 & 7.8 & 7.4 & 8.1 & 8.0 & 7.8 & 7.8 & 8.2 & 8.0 \\
\hline $\begin{array}{l}\text { 4. I get on with my } \\
\text { fellowworkers }\end{array}$ & 8.5 & 8.5 & 8.4 & 8.6 & 8.7 & 8.6 & 8.3 & 8.9 & 8.3 & 8.5 & 8.4 \\
\hline $\begin{array}{l}\text { 5. My immediate superior } \\
\text { performs as a superior }\end{array}$ & 7.5 & 7.5 & 7.6 & 7.9 & 7.6 & 8.1 & 6.7 & 7.4 & 7.3 & 7.2 & 7.3 \\
\hline $\begin{array}{l}\text { 6. How certain are you that } \\
\text { you will keep job with this } \\
\text { employer? }\end{array}$ & 7.3 & 6.9 & 8.3 & 8.0 & 7.9 & 8.1 & 7.9 & 7.6 & 7.3 & 8.0 & 7.7 \\
\hline $\begin{array}{l}\text { 7. How much can you } \\
\text { influence factors concerning } \\
\text { your job? }\end{array}$ & 6.8 & 6.7 & 7.1 & 7.4 & 7.3 & 7.6 & 6.5 & 7.6 & 7.0 & 6.6 & 6.8 \\
\hline
\end{tabular}

\section{ANALYSIS}

Using the QSPNordic questionnaire the lowest scores were given to the first question: the superior does not take always into account the opinion of the employee (score 3.07 from 5.0 possible). The highest score (4.33) was given by the employees of the successful energy firm to the future perspectives of the enterprise. Thus, they were not afraid of losing their jobs. It seems that the high school workers are more demanding and more sensitive to the work conflicts. There is no score over 4.0 speaking about the high school personnel over 40 years. It is also obvious that in the enterprises (compared to the high school) the workers give better marks to their managers.

In the Kiva questionnaire the lowest mark (5.7) was given by the service enterprise workers under 40 years old (they were not very eager of going to work every day). The highest mark (9.1) was given by the energy enterprise workers over 
40 years old to the meaningfulness of their work. It can be said that the most stressful factors for the workers is the fact that they cannot influence the factors concerning their own job. The arrangement of the workrooms (single room or opened office) does not influence the relationship between the coworkers (the 4th question in KIVA). If the enterprise is in a good position economically (A), then the workers appreciate the employer (7th question in QPSNordic).

\section{V.CONCLUSIONS}

It is necessary to treat the workers fairly and equally, then they feel satisfaction of their work. Metal Age program [14] is the mean for training the workers and employers to decrease stress in the work environment and to prevent the possibilities for developing the musculoskeletal disorders (MSDs). The indoor air hazards may disturb the workers, but if the employer discusses the problems with the workers, then these shortages could be easily solved.

\section{REFERENCES}

[1] K. Reinhold, P. Tint, V. Tuulik and S. Saarik, "Innovations at workplace: improvement of ergonomics," Engineering Economics, 60, pp. 85-94, 2008.

[2] P. Tint, A. Traumann, V. Pille, V.-R. Tuulik-Leisi and V. Tuulik, "Computer users' health risks caused by the influence of inadequate indoor climate and monotonous work," Agronomy Research, 10, pp.261-276, 2012.

[3] P. Tint and A. Traumann, "Health risk assessment in atrium-type buildings," International Journal of Energy and Environment, 6, pp.389396, 2012.

[4] K.Reinhold, M.Järvis and P.Tint, "Risk observatory - a tool for improving safety and health at workplace," International Journal of Occupational Safety and Ergonomics, 15, pp.101-112, 2009.

[5] National Labour Inspectorate, "Annual Report of Work Environment 2011," [Online]. Available: http://www.ti.ee/public/files/Annual\%20Rep ort\%20on\%202011(1).pdf. [Accessed May, 28, 2013].

[6] J. Reste, M. Eglite, A. Rubine, J. Cirule, G. Zubkova, T. Zvagule and I. Vanadzins, "Musculoskeletal disorders caused by physical overload: the situation in Latvia," WIT Transactions on biomedicine and health, 16, pp.73-81, 2013.

[7] P.Tint, Õ. Paas and K.Reinhold, "Cost-effectiveness of safety measures in enterprises," Inzenerine Ekonomika - Engineering Economics, 21, pp. 485-492, 2010.

[8] N.I. Eisenberger and S.W. Cole, "Social neuroscience and health: neurophysiological mechanisms linking social ties with physical health", Nature Neuroscience, 15, pp.1-6.

[9] J. Holt-Lunstad, T.B. Smith and J.B. Layton, "Social relationship and mortality risk: a meta-analytic review," PLoS Med., 7, e1000316, 2010. http://dx.doi.org/10.1371/journal.pmed.1000316

[10] G. Miller, E.Chen, and S.W. Cole, "Health psychology: developing biologically pausible models linking the social world and physical health. Ann. Rev. Psychol., 60, 501-524, 2009. http://dx.doi.org/10.1146/annurev.psych.60.110707.163551

[11] I. Seppo, J. Janno, E. Kallaste, L.Kraut and M.Voitka, "Psühholoogiliste riskide levik Eestis"-The National Labour Inspectorate, 2010- In Estonian, The spread of the psychological risk factors in Estonia. Online: Available: http://rahvatervis.ut.ee/bistream/1/1901/1/Seppojt201 $\underline{0 . p d f}$

[12] R. Gould, J. Ilmarinen, J. Järvisalo and S. Koskinen, Dimensions of Work Ability, Finnish Centre for Pensions, Helsinki, 2008.
[13] K. Lindström, A.-L. Elo, A.Skogstad, M. Dallner, F. Gamberale, V. Hottinen, S. Knardahl and E. Orhede, General Nordic Questionnaire for psychological and social factors at work. 2000. http://www.norden.org/en/publications/publikationer/2000603/at_download/publicationfile

[14] O. Näsman. Metal Age and Kiva-questionnaire. Assist in navigation towards well-being at work. Mediona OyAb. The Aechipelago Academy for Well-being at Work http://www.mediona.fi/pdf/KANSI\%20Metal\%20Age\%20ja\%20Kivakysely\%

Piia Tint, Chemical Engineer (1970, Tallinn Technical University), Candidate of Technical Sciences (1977, Leningrad Technological Institute of Lensoveta), occupational health and safety.

Piia Tint is a Professor of Work Environment and Safety, the Head of the Department of Work Environment and Safety, Tallinn University of Technology, Estonia, since 2000.

Piia Tint has written 150 scientific papers, 10 books; the best scientific paper: K.Reinhold and P.Tint, "Hazards Profile in Manufacturing: Determination of Risk Levels towards Enhancing the Workplace Safety," Journal of Environmental Engineering and Landscape Management, 17, pp.69-80, 2009. The main research interests: risk assessment in the work environment, chemical risks.

She is a supervisor of $6 \mathrm{PhD}$ students (1 defended).

E-mail: piia.tint@ttu.ee

\section{Viiu Tuulik}

A degree of Doctor of Medicine was awarded by Tartu University in 1993; a degree of Master of Medical Sciences was awarded by Tartu University in 1974.

Viiu Tuulik works as a Senior Researcher at the Department of Biomedical Engineering, Technomedicum of Tallinn University of Technology.

The main research interests: occupational stress caused by chemicals, physiology, musculoskeletal disorders. Viiu Tuulik has more than 40 years of experience in occupational health. Viiu Tuulik is the author of 100 scientific papers.

The best paper: A.Traumann, P.Tint and V.Tuulik, "Indoor Air Quality in Educational Institutions in Estonia," Environmental Engineering and Management Journal, 11, pp.207-214, 2012.

E-mail:viiu@cb.ttu.ee

Deniss Karai, secondary education.

Deniss Karai works as a Technician at the Department of Biomedical Engineering. He has a lot of experience in different technical topics. Main research areas: different physiological signal registration, signal processing, device prototyping, algorithm implementation, software development, scientific device maintenance and installation. Deniss Karai is the author of 35 papers.

The best paper:

D.Karai, S.Kostin, I.Fridolin, R.Ubar, "Accurate Dialysis Dose Evaluation and Extrapolation Algorithms during On-line Optical Dialysis Monitoring," IEEE Transactions on Biomedical Engineering, 60, pp.1371-1377, 2013.

E-mail: deniss@cb.ttu.ee

\section{Kalju Meigas}

A degree of Master of Technical Sciences was awarded by Tallinn University of Technology in 1993; a degree of Doctor of Technical Sciences was awarded by Tallinn University of Technology in 1997.

Kalju Meigas works as a Director of the Technomedicum of TTU, Professor. Kalju Meigas is the author of 100 scientific papers and patents. Kalju Meigas participated in 10 international projects.

Kalju Meigas is a supervisor of $5 \mathrm{PhD}$ students ( 1 defended). The main interests: biomedical equipment, biomonotoring of workers' health. The best scientific paper:

J.Kaik, K.Meigas, J.Abina, T.Sipilova, I.Psenitsnikov, D.Karai, J.Riipulk, "Dynamics of Arterial Hypertension and Other Cardiovascular Risk Factor Prevalence in Tallinn Women Population", Kardiologija, 50, pp.40-46, 2010. E-mail: kalju@cb.ttu.ee 